\title{
Species composition and diversity of legumes in sal plantations of north-eastern Uttar Pradesh, India.
}

Sanjay Kumar Pandey

Department of Botany, SMP Government Girls Degree College, Ballia, UP. 277 401, India.

Received: 5/29/2017; Revised: 8/12/2017; Accepted: 8/29/2017

\begin{abstract}
The present study aims to compare the composition, diversity and distribution pattern of legumes vs. non- legumes in the regional sal forest of north- eastern Uttar Pradesh, India. In order to show pattern of change in different phytosociological data, the species of similar habits were sorted into different habit groups. In addition to usual regeneration through seeds, a number of legumes also showed non- seed regeneration strategy. As many as $57 \%$ of the total legume individuals were of ramet origin but belonged only to $5 \%$ of the legumes of forest. The presence of legumes with 41 species (out of 246 in regional forest) sharing $17.7 \%$ of importance value (IVI) in sal forest was noticeable. About one third total individuals in forest were herbaceous. Mean density for legume trees was $>6$ per ha while it was $>6000$ per ha for legume shrubs. Moghania chappar, M. lineata, M. bracteata and Desmodium gangeticum were most abundant legume shrubs in regional sal forest. The general rank- abundance curve for regional sal forests was quite steep and close to log normal curve. The legume diversity is crucial for nutritional status of forest soil and legumes are known to heal the disturbed forest. Besides information on the present status of common leguminous vs. non- leguminous species, the results provide clues for the management option in these forests and for the maintenance of legume diversity in such stochastic environment.
\end{abstract}

Keywords: sal forest, legumes, diversity, rank- abundance graph, non- seed regeneration, habit groups

\section{Introduction}

The forested landscape of eastern Uttar Pradesh (terai plains) of India is geographically a part of great belt of sal (Shorea robusta Gaertn.) forests and presents a mini-centre of biodiversity especially of woody and non-woody perennials plants. The sal is planted in this region mostly through taungya cultivation (Champion and Seth 1968). As the sal ages the species diversity has been at satisfactory level in the undisturbed conditions but the increasing anthropogenic disturbances from catchment area have caused severe perturbations to the associated communities. Normally the composition of these plantation forests has been found to be quite similar to that of natural growth forests of the region as the sal trees dominate the overstorey of the natural growth forests as well (Pandey and Shukla 2001). These plantations constitute number of leguminous and nonleguminous species populations exhibiting different growth habit (Pandey 2000) but different sorts of recurrent anthropogenic disturbances have drastically changed the structure and diversity pattern of these communities. The most grave situations for the species survival arises when those meagre number of species, growing as associates of planted timber, are also not spared and deliberately eliminated in the interest higher growth of planted timber. Each forest has a distinct floristic composition which varies in its species richness and abundance of different

\section{*Corresponding Author:}

\section{Dr. Sanjay Kumar Pandey,}

Asst. Professor, Department of Botany,

SMP Government Girls Degree College,

Ballia, Uttar Pradesh, India.

E-mail: drskp27@gmail.com species. Environmental variability in terms of climatic factors, soil conditions, grazing by herbivores and human interference are critical factors which regulate the spatial and temporal pattern of vegetation of an ecosystem (Chapin et al., 1993). The habitat destruction, over exploitation and species introduction are identified as major causes of biodiversity loss (UNEP 2001).

Plants are assumed to propagate both by producing seeds that scatter over the population and through vegetative reproduction within the neighbouring vacant sites (Cook 1983). Sprouting may maintain certain species in several forests communities (Whitmore 1984) and non-seed regeneration is of wide occurrence in harsh condition (Calaghan 1988). Khan et al., (1987) and Barik et al., (1996) described the effect of disturbance on the species composition and regeneration pattern in the forest ecosystem and concluded that they are strongly influence by burning, clear- felling, grazing and shifting cultivation. As the vegetation cover under natural growth forests has been fast receding, managed forests are the only alternative for the conservation of wild plants (Halpern and Spies 1995). It is amply clear that biodiversity is essential for human survival and economic well being and ecosystem stability (Murali et al., 1996, Singh 2002). Hubbel et al., (1999) pointed out that disturbances created by 


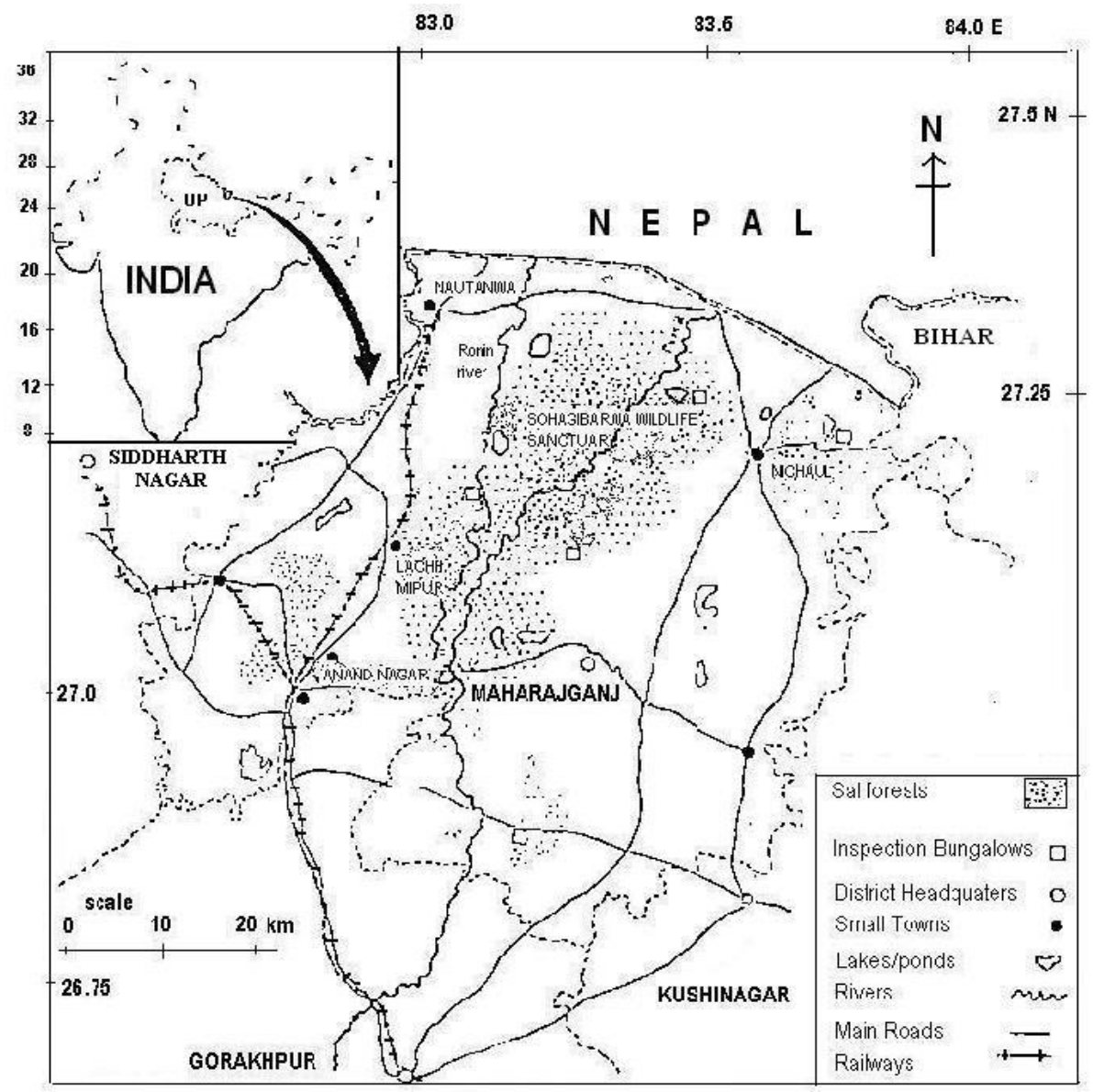

Figure 1. Study site shown within the Sohagibarwa Wildlife Sanctuary in the Gorakhpur Forest Division, India.

these factors determine forest dynamics and tree diversity at the local and regional scales.

In sal forests, $S$. robusta is generally the most imperative species occupying the majority of density, importance value and even greater proportion of basal area. Previously, sal forests were regarded less diverse in terms of species richness, as not many associated species and their individuals were suitable for timber extraction. But latter, study revealed that the species diversity is much higher in sal forests than previously supposed (Umashankar 2001, Pandey and Shukla 2001, Kushwaha and Nandy 2012). The forest vegetation in general and tropical forests in particular, are very well studied world over (Knight 1975, Gentry 1995, Hubbell et al., 1999) and analysis of a good many Indian forest vegetation is also available (Daniels et al., 1995, Sagar and Singh 2005, Majumdar et al., 2012, Deka et al., 2012, Gautam et al., 2014, Tiwari and Uma Shankar 2014). Due to continued alteration of the habitat through anthropogenic disturbances, the resulting landscapes are acting as 'death traps' for several wild species of socio-economic importance. Wild legumes form an important understorey component as they not only provide fuel wood, medicine and many more but also fixed nitrogen to soil and valuable proteins to the wild animals like those of agro-ecosystems do to the agricultural fields and to the human beings and their domesticated animals (Isely 1982). The forested landscape of north-eastern U.P. is, however, little explored for its community attributes and diversity pattern but no work is available on the comparative account of leguminous vs. nonleguminous components of this vegetation. The present study provides information on the contribution, regeneration and distribution pattern of legumes in the regional sal forest.

\section{Materials and Methods}

\section{Study sites and vegetation}

The study was conducted in Sohagibarwa Wildlife Sanctuary under Gorakhpur Forest Division, UP. The sanctuary is located between $27^{\circ} 05^{\prime}$ and $27^{\circ} 25^{\prime} \mathrm{N}$ latitude and $83^{\circ} 20^{\prime}$ and $84^{\circ} 10^{\prime} \mathrm{E}$ longitude and at $95 \mathrm{~m}$ altitude (Figure. 1). The climate is seasonal and sub-tropical. The total average annual rainfall is about $1814 \mathrm{~mm}, 87 \%$ of which occurs during the wet summer or monsoon season. During the relatively dry period of about 8 months, i.e. January-June and November- 
December the monthly rainfall is less than 100 $\mathrm{mm}$. The soil is old Gangetic alluvium. The texture is sandy loam and the soil reaction is circumneutral. The regional forest of north-eastern UP is of subtropical semi-evergreen type with a number of deciduous elements. Of the total $428.2 \mathrm{~km} 2$ forested area of the sanctuary, $2.32 \%$ is still under the natural, semi-evergreen forest vegetation. The deciduous plantations of Gorakhpur Forest Division consist mostly of sal (Shorea robusta Gaertn), planted mainly through taungya system. In this system, the clear-cutting of natural-growth forests follows the operations like ground-clearing by landless farmers (also called taungya), who plough the site and use the land for taungya cultivation (Champion and Seth 1968). Freshlycollected sal seeds are sown in lines at intervals of about 10 feet between any two lines and the interline spaces are used to cultivate cereals, pulses and vegetables for 2-3 consecutive years. Once the sal saplings get established, their rows cast shade, rendering the site unsuitable for supporting any more agricultural crops. Now the site is abandoned, the sal saplings are left to grow naturally and ecological succession sets in. As the sal ages, the associated vegetation also develops naturally and gains considerable species diversity. Of these, several over- and understorey trees, a number of shrubs and some perennial herbs may grow as sal associates.

\section{Field survey and data analysis}

Twenty-four sal stands were identified along a 30$\mathrm{km}$ long forest belt, starting from periphery to the core of the Sohagibarwa Wildlife Sanctuary. The age of the identified forest stands was found to be $50 \pm 10$ years. A hectare -plot, showing average vegetation for the stand, was marked for sampling in each of the 24 stands. Each plot was divided into 4 quarters and each quarter was further subdivided into 25 quadrats each of $10 \mathrm{~m} \mathrm{X} \square 10 \mathrm{~m}$ size. Trees and undertrees of $\geq 30 \mathrm{~cm}$ gbh were counted in all the 25 quadrats of each quarter. For accounting the individuals of $\leq 30 \mathrm{~cm}$ gbh, only 10 random quadrats per quarter, i.e. a total of 40 quadrats $(0.40$ hectare $)$ per hectare plot were observed. The data, however, were suitably multiplicated to represent them on per hectare basis. Stratified random sampling approach was followed for phytosociological survey in the study. The GBH of all the tree species was measured at $1.37 \mathrm{~m}$ from the base during the sampling. Basal area of each individual tree species was calculated following $\mathrm{g} 2 / 4 \Pi$ where $\mathrm{g}=$ Girth $(\mathrm{cm})$. Plant species encountered in each quadrat was listed according to their habit groupa and identified on the basis of available floristic account of regional flora (Srivastav 1976). The frequency values of the constituent species of different habit groups was sorted under five frequency classes and the number of species falling these frequency classes was represented in the form of histograms. The phytosociological parameters such as density, basal area and Importance Value Index (IVI) were computed and derived through conventional methods (Mueller- Dombois \& Ellenberg 1974). IVI was taken as the sum of relative frequency, relative density and relative basal cover (relative ground cover in case of herbs) where the relative values of frequency, density and cover were derived as the value for a species, expressed as percentage of the sum of the values for all the species of a community. These values for legumes and non- leguminous shrubs and trees were compared. A comparison of dominance- diversity curves for leguminous and non- leguminous species was also made. The diversity was determined as Shannon's index $\left(\mathrm{H}^{\prime}=-\sum \mathrm{pi} \ln \mathrm{pi}\right)$, where, pi represents the proportional abundance of $\mathrm{i}^{\text {th }}$ species in the community (Magurran 1988).

The non- seed regeneration was categorized into two broad types: by sprouting and by ramet producing. A Number of species could regenerate by their sprout shoots from the remaining stumps. The species producing 1- 2 sprouts were treated as least- sprouters, those producing 3-5 sprouts were considered as moderate sprouters and those producing $>5$ sprouts per stump were termed as high sprouters. Saplings and mature individuals of few legumes could develop root- suckers on subterranean rootstock at a considerable interval from the parent shoot. These root- suckers develop into a new individual or ramet (Silvertown 1987). They were distinct over- ground but actually interconnected by subterranean spacers. The pattern of initial shoot growth of ramet was quite different from that of an individual directly from seed i. e. genet.

\section{Results and Discussion}

The legumes are regarded as one of the most successful families of flowering plants in the world due to the extreme flexibility of their adaptive responses to different environments (Rundel 1989). The total number of species encountered in the community analysis of the regional sal was 246 . It had 93 species in tree form (>30 cm gbh) followed by shrubs (67), lianas (38) and perennial herbs (48). Trees species was higher then than reported for eastern Himalayan (Umashankar 2001, Deka et al., 2012, Tripathi and Umashankar 2014) but lesser than reported from moist sal forest of West Bengal (Kushwaha and Nandi 2012). Leguminaceae is the most prominent family in Indian deciduous forests (UmaShankar1998). In present study also the Papilionaceae was observed to be the dominant family as it is represented by 24 species followed by 12 in caesalpiniacea while mimosaceae by 5 species only. 451 tree individuals/ hectare were recorded which matches the data given by Majumdar et al., (2012) for primary sal forest of Tripua and by Kushwaha and 
Nandi (2012) for moist sal forests of West Bengal. The proportion of trees, shrubs, climbers and legumes of this forested landscape fairly matched the composition of Western Ghats (Daniel et al., 1995). However, this was much lower in comparision with the tropical rain forests of Barro Colorado Island (Knight 1975).

Table 1 showed the list of 41 perennial legumes of different habits encountered in regional forested landscape. Tree species were highest followed by shrubs and legume climbers. Among legume trees, mean density per hectare was maximum for Cassia fistula. This was the only tree species having more than 1 importance value. M. chappar, M. bracteata, $M$. lineata and $D$. gangeticum contributed much to the numerical strength of individuals and to sum of basal area. Species like M. prostrata, D. latifolium and Uraria picta were the rarest shrubs. All the other shrubs showed much smaller importance value. The proportion of fortuitous belonging to class A (having frequency of $<20 \%$ ) was maximum and much greater for any habit groups. While the leguminous and non-leguminous shrubs and herbs followed the trend of normal frequency distribution (the sequence was $\mathrm{A}>\mathrm{B}>\mathrm{C}>\mathrm{D}$ ). The species of trees and woody climbers showed quite aberrant frequency distribution. The percent number of leguminous species under class B and C was almost equal. The regional forest in general, showed much greater proportion of class $\mathrm{A}$ and least of class $\mathrm{E}$. The relative percentage of frequency class $\mathrm{B}, \mathrm{C}$ and $\mathrm{D}$, however, were near normal (Figure. 2).

Table 1. The legume component of sal forest showing constituent species of different habits (T: trees, S: shrubs, C: climbers and H: herbs with their families.

\begin{tabular}{|c|c|c|c|c|c|c|}
\hline \multirow{2}{*}{ Species } & \multirow{2}{*}{ Family } & \multirow{2}{*}{ Habit } & \multicolumn{2}{|c|}{ Density/ Ha } & \multirow{2}{*}{$\begin{array}{c}\text { Basal area } \\
\mathrm{cm}^{2} / \mathrm{Ha}\end{array}$} & \multirow[t]{2}{*}{ IVI } \\
\hline & & & $\geq 30 \mathrm{~cm} \mathrm{gbh}$ & $\leq 30 \mathrm{~cm} \mathrm{gbh}$ & & \\
\hline Abrus precatorius $\mathrm{L}$. & Papilionaceae & $\mathrm{C}$ & 0 & 1.8 & 9.22 & 0.24 \\
\hline Aacacia nilotica (L.) Del & Mimosaceae & $\mathrm{T}$ & 0 & 0.3 & 0.28 & 0.11 \\
\hline Acacia catechu Willd. & Mimosaceae & $\mathrm{T}$ & 0.04 & 0.41 & 6.82 & 0.12 \\
\hline Albizia lebbeck (L.) Benth. & Mimosaceae & $\mathrm{T}$ & 0.04 & 0.3 & 0.31 & 0.11 \\
\hline Baubinia malabarica Roxb. & Caesapiniaceae & $\mathrm{T}$ & 1.25 & 26.7 & 148.7 & 0.43 \\
\hline Baubinia purpurea L. & Caesapiniaceae & $\mathrm{T}$ & 0.12 & 4.2 & 18.1 & 0.25 \\
\hline Baubinia vablii $\mathrm{W}$. EA. & Caesapiniaceae & $\mathrm{C}$ & 0.12 & 105.4 & 84.54 & 1.69 \\
\hline Baubinia variegata $\mathrm{L}$. & Caesapiniaceae & $\mathrm{T}$ & 0.12 & 1.4 & 12.4 & 0.69 \\
\hline Butea monosperma (Lamk.) Tabu. & Papilionaceae & $\mathrm{T}$ & 0.04 & 1 & 7 & 0.12 \\
\hline Caesalpinia bonducella Flem. & Caesapiniaceae & $\mathrm{C}$ & 0 & 31.3 & 90.1 & 0.53 \\
\hline Caesalpinia crista $\mathrm{L}$. & Caesapiniaceae & $\mathrm{C}$ & 0 & 3.3 & 12.9 & 0.26 \\
\hline Caesalpinia sepiaria Roxb. & Caesapiniaceae & $\mathrm{C}$ & 0 & 2.1 & 10.8 & 0.13 \\
\hline Cassia fistula $\mathrm{L}$. & Caesapiniaceae & $\mathrm{T}$ & 2.75 & 51.7 & 235.2 & 1.16 \\
\hline Cassia nodosa Buch. ham. & Caesapiniaceae & $\mathrm{T}$ & 1.92 & 4.6 & 151.1 & 0.33 \\
\hline Cassia tora $\mathrm{L}$. & Caesapiniaceae & $\mathrm{S}$ & 0 & 4 & 5.12 & 0.36 \\
\hline Crotalaria alata & Papilionaceae & S & 0 & 2 & 0.64 & 0.35 \\
\hline Crotalaria prostrata & Papilionaceae & $\mathrm{H}$ & 0 & 1 & 0.1 & 0.12 \\
\hline Crotalaria sp. & Papilionaceae & $\mathrm{H}$ & 0 & 1 & 0.32 & 0.24 \\
\hline Dalbergia lanceolaria L. f. & Papilionaceae & $\mathrm{T}$ & 0.04 & 12.1 & 15.8 & 0.41 \\
\hline Dalbergia sissoo Roxb. & Papilionaceae & $\mathrm{T}$ & 0.08 & 2 & 185.1 & 0.2 \\
\hline Desmodium gangeticum (L.) Dc. & Papilionaceae & $\mathrm{S}$ & 0 & 808.5 & 258.72 & 6.16 \\
\hline Desmodium heterocarpon (L.) Dc. & Papilionaceae & $\mathrm{S}$ & 0 & 24.4 & 7.8 & 0.8 \\
\hline Desmodium latifolium Dc. & Papilionaceae & S & 0 & 0.08 & 0.02 & 0.11 \\
\hline Desmodium pulchellum (L.) Benth. & Papilionaceae & $\mathrm{S}$ & 0 & 621.3 & 447.3 & 5 \\
\hline Desmodium triangulare (Retz.) Merr. & Papilionaceae & S & 0 & 17 & 5.4 & 0.31 \\
\hline Erythrina indica Lamk. & Papilionaceae & $\mathrm{T}$ & 0.12 & 0.12 & 15.5 & 0.12 \\
\hline Indigofera hamiltoni $\mathrm{R}$. Grah. & Papilionaceae & S & 0 & 22.1 & 28.3 & 0.46 \\
\hline Męoneurum cucullatum W.\&A. Prodr. & Papilionaceae & $\mathrm{C}$ & 0 & 0.2 & 0.4 & 0.11 \\
\hline Milletia auriculata Baker & Papilionaceae & $\mathrm{C}$ & 0.12 & 35.8 & 148.9 & 1.37 \\
\hline Mimosa pudica $\mathrm{L}$ & Mimosaceae & $\mathrm{S}$ & 0 & 2 & 0.64 & 0.24 \\
\hline Moghania bracteata (Roxb.) L. & Papilionaceae & $\mathrm{S}$ & 0 & 994.2 & 974.3 & 7.19 \\
\hline Moghania chappar (Benth.) Kuntze & Papilionaceae & $\mathrm{S}$ & 0 & 2669 & 1921.7 & 15.5 \\
\hline Moghania lineata (L.) Ktze. & Papilionaceae & S & 0 & 959.2 & 306.9 & 6.78 \\
\hline Moghania prostrate Roxb. & Papilionaceae & S & 0 & 0.12 & 0.5 & 0.16 \\
\hline Ougeinia dalbergioides Benth. & Papilionaceae & $\mathrm{T}$ & 0.04 & 0 & 6.5 & 0.11 \\
\hline Peltophorum pterocarpum (Dc.) Baker & Caesapiniaceae & $\mathrm{C}$ & 0 & 0.04 & 0.1 & 0.11 \\
\hline Pithecellobium dulce (Roth.) Benth. & Mimosaceae & $\mathrm{S}$ & 0 & 5 & 10 & 0.13 \\
\hline Pongamia pinnata (L.) Pierrc & Papilionaceae & $\mathrm{T}$ & 0.12 & 2.4 & 11.1 & 0.12 \\
\hline Pterocarpus marsupium Roxb. & Papilionaceae & $\mathrm{T}$ & 0.04 & 0 & 21.5 & 0.12 \\
\hline Tamarindus indica $\mathrm{L}$ & Caesapiniaceae & $\mathrm{T}$ & 0.12 & 0.12 & 78.1 & 0.14 \\
\hline Uraria picta (Jaeq.) Desv. & Papilionaceae & $\mathrm{H}$ & 0 & 0.5 & 0.2 & 0.11 \\
\hline Total legumes & & & 7.08 & 6418.69 & 5238.43 & 53 \\
\hline Contribution of legumes (\%) & & & 1.7 & 12.6 & 2.2 & 17.7 \\
\hline Total in Regional Sal Forest & & & 451 & 51,091 & 241539 & 300 \\
\hline
\end{tabular}




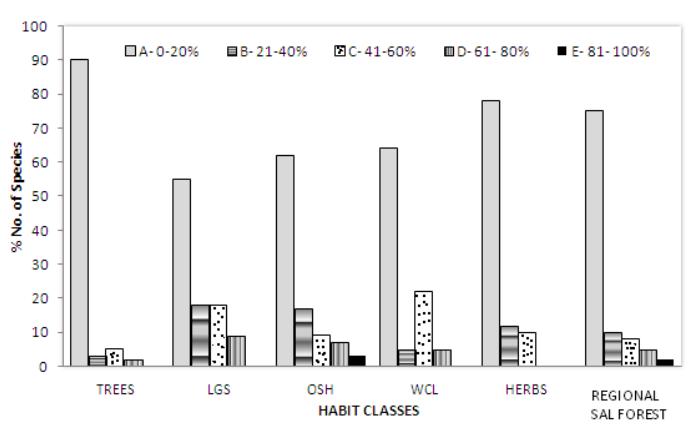

Figure 2. Frequency- class distribution of species in different habit groups as well as sal forest of north estern UP. (TREES- individuals $>30 \mathrm{~cm}$ gbh; LGSlegume shrubs; OSH- non-legumes; WCL- woody climber; HERBS- all herbaceous plants).
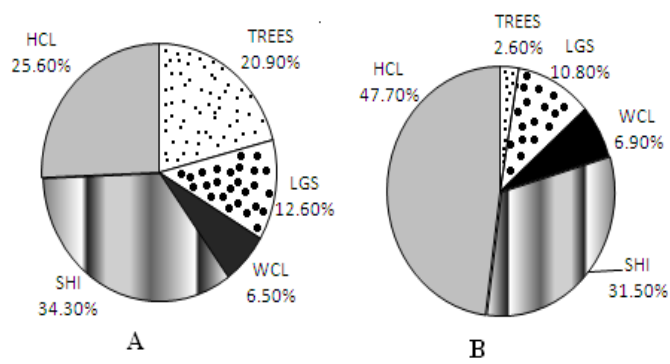

Figure 3. Proportion of number of species (A) and percent contribution to $\mathrm{H}$ (B) of different habit groups in regional sal forest. (TREES- individuals > $30 \mathrm{~cm}$ gbh; LGS- all legume shrubs; SHI- all nonleguminous shrub; WCL- woody climber; HCL- all herbaceous plants).

The data on the regional forested landscape showed that the percentage of species of leguminous shrubs (LGS) was 12\%. It was $6.5 \%$ for woody climbers (WCL). The shrubby individuals (SHI) made a contribution of about $32 \%$ to the diversity of regional forested landscape. However, herbs and herbaceous climber contributed maximum $(47.7 \%)$ to the diversity of regional forested landscape. The same was also observed in moist sal forest in West Bengal (Kushwaha and Nandi 2012). Among the other components, LGS contributed maximum $(10.9 \%)$ followed by WCL $(6.9 \%)$ and trees $(2.6 \%)$ (Figure. 3 A, B). A hectare of forest vegetation had $451 \pm 53$ individuals of trees $(\geq 30 \mathrm{~cm}$ gbh). Most of the tree species were also encountered as shrubs. LGS accounted for $6418 \pm 511$ and the WCL for 2,900 \pm 249 individuals/ hectare. Approximately one third of the total individuals comprising the vegetation were herbaceous. The number of SHI was maximum ( $\sim 25$ thousands/ hectare) followed by that of herbs (Figure. 4). The probable reason for supporting low number of species, other than climate, may be due to loss of natural associations. It is argued that they do not exit independently, the have co-evolved in ecosystem on which they depend (Paine 1966). Thus if our actions cause the elimination of any species (as in plantation forests) this may lead to elimination of several other species as well. Therefore, the emphasis on only commercial trees has created a serious problem and a colossal ecological loss. Disturbance does effect the growth and overall performance of plantation forests and their associated species. Further the growth of associates is necessary for efficient nutrient recovery and soil conservation in the system (Kimmins 1987).

Mechanism of regeneration may differ for different legumes as determined by their growth features and type of disturbance. Among total legumes, the regeneration status, expressed on the basis of the relative proportion of individuals at the seedling, sapling and mature stages was good for $17 \%$, fair for $39 \%$ and $22 \%$ species each falling under both poor and very poor category. Majority of legume trees and shrubs showed fairly high regeneration. In general, regeneration of liana was poor. Legume shrubs showed comparatively fair regeneration status (Figure. 5). There was strong negative correlation between the number of individuals of legume and their species richness ( $\mathrm{r}$ $=-0.92$ ), only six species (HS and ramet producers) contributed $>90 \%$ of total individuals. Fourteen legumes were moderate sprouters, while 21 were least sprouters. As many as $57 \%$ of the total legume were of ramet origin but belonged only to $5 \%$ of the legume species of forest. Least sprouters showed a much smaller individual share $(4 \%)$ but had legume species richness more than $50 \%$ (Figure. 6). In general, Moghania, showed much greater sprouting than Desmodium at low to moderate disturbances and had maximum number of sprouts in regional sal forest. Few young genets and sprouts of leguminous shrubs were also encountered in some safe pockets of highly disturbed sal forests. Study showed that, moderately disturbed sal forests had considerable number of sprouts/ramets of legumes trees and shrubs (Pandey and Shukla 2001). Generally, ramet producing legumes were also prolific sprouters. These sal forest stands had good number of moderate and high sprouters as reported elsewhere (Barik et al., 1996). It may be asserted that at critical level of disturbance, the species lacking as non- seed regeneration strategy might have gradually been pushed towards rarity of even disappearance (Daniels et al., 1995).

The abundance with IVI value based relationship for different legumes followed a fair log-normal pattern of resource sharing with a few common species with high abundance (e.g. Moghania and Desmodium spp.), several intermediate species with moderate abundance and some very rare species with very low abundance (Figure. 7). The initial flattering of the curve was due to a good number of commonly occurring legume species, $M$. chappar, $M$. lineata, M. bracteata and D. gangaticum. On the other hand, the four-rare species Abrus precatorious, 
D. latifolium, Butea monospora and Erythrina indica were towards the sloppy end of the curve.

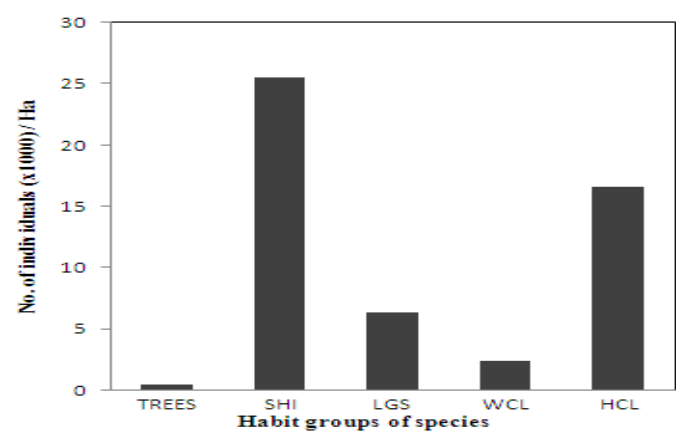

Figure 4: The total number of individuals/ ha of different habit groups of species of regional sal forest.

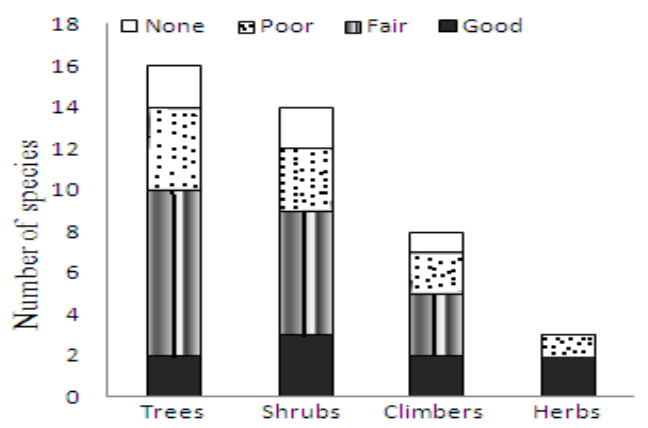

Figure 5: For tree and climbers: Good- seedling $>$ sapling $>$ adult; Fair-seedling $>$ sapling $<$ adult; Poorspecies is represented by saplings only, but not as seedling; None- species present only as adult seedling $=<10 \mathrm{~cm}$ gbh; sapling $=10.1$ to $<30 \mathrm{~cm}$ gbh; adult $=>30 \mathrm{~cm}$ gbh).

For shrubs and herbs: Good- seedling $>$ mature $>$ adult; Fair- seedling $>$ mature $<$ adult; Poor- species is represented by mature only, but not as seedling; None- species present only as adult. seedling $=<1 \mathrm{~cm}$ gbh.; mature $=1.1$ to $<10 \mathrm{~cm}$ gbh.; adult $=>10 \mathrm{~cm}$ gbh .

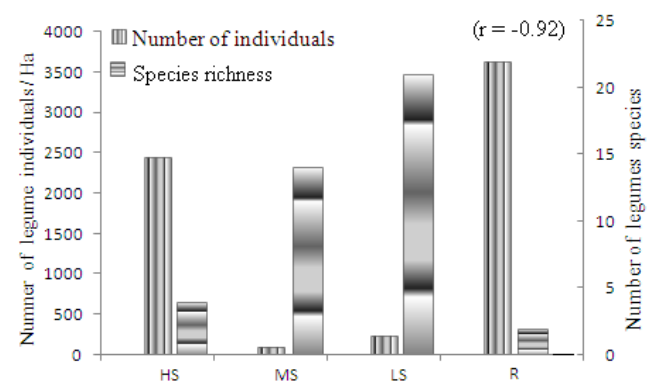

Figure 6: Number of legumes/ ha and legume species richness grouped under different categories of non-seed regeneration. HS- High sprouting; MS- Moderate sprouting; LS- Least sprouting; $\mathrm{R}$ - Ramet producing roots.

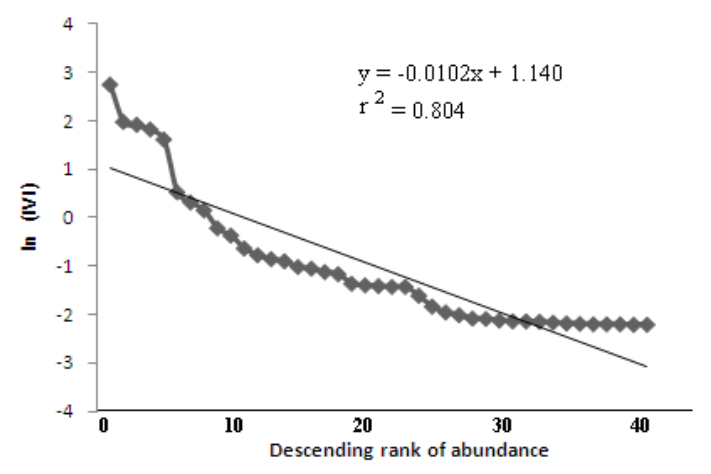

Figure 7: Pattern of distribution of legumes in sal forest of north- eastern U. P. in a rank abundance graph based on ln IVI of species.

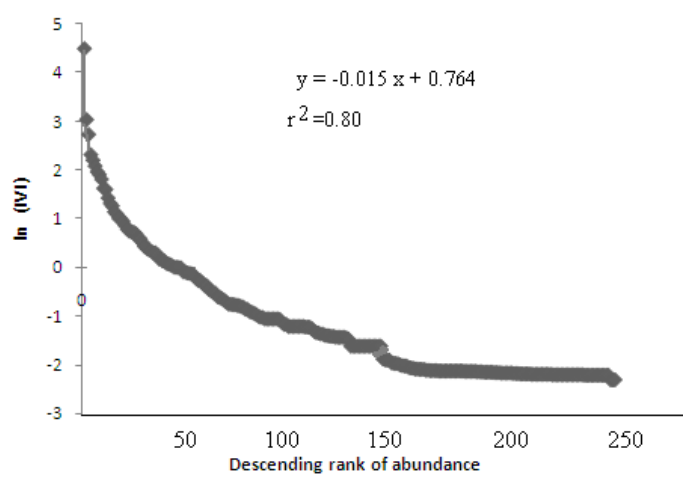

Figure 8: Distribution pattern of different species in sal forests of north- eastern U. P. in a rank abundance plot based on $\ln$ value of importance value.

The curvature of the rank/ abundance graph is often used to deduce which species abundance model best describes the data (Magurran 1988). In regional sal forest, general rank/abundance plot based on importance value of species was fairly convex but became very steep towards the end, which signify the log series distribution. The most dominant species causing steepness to curve were Shorea robusta, Mallotus philippensis, Clerodendron infortunatum and $M$. chappar. Rare species of the regional forests making the tail end of the curve were Alstonia scholaris, Rawwolfia serpentine and D. latifolium (Figure.8). The latter two species were very rare. The curve has often been used to interpret the community organization in terms of resource share and niche space. The curves of regional forest fit the geometric series which also conforms to the niche preeption hypothesis of Whittaker (1975). As evident from these curves for different habit groups, the few dominant species utilized relatively much greater resources, thus preemped much more niches in regional forests. With an increase in disturbance, the abundance of poorly sprouting species decreased allowing other species to share community resources. On the other hand, species showing efficient sprouting increased to the extent of their dominance. 
Diversity is the outcome of the co-evolution of species in a bio-geographic region. It is often considered to be a synthetic measure of the structure, complexity and stability of a community (Hubbell and Foster 1983). The Shannon's index of diversity for the present sal forest was 3.53. The value is, however, lower than that recorded in tropical rain forest of BCI (4.8, knight 1975) but higher than that for unmanaged moist deciduous forest of Northern India (1.05 -2.89; Gautam et al., 2014) and sal forest of Assam (1.43 -3.28; Deka et al., 2012). The data show that this regional forested landscape still has considerable diversity of legumes and associated species. The legumes not only help maintain community attributes of the sal forests but also contribute towards the conservation of overall biodiversity. Legumes can provide good understorey cover even in presence of considerable disturbance and thus can add to the maintenance of ecosystem attributes of the disturbed forests. The overview of regional forests may provide clues for guided extraction and careful management in order to save plant diversity without hampering resource extraction significantly.

\section{Acknowledgements}

Thanks to Ranger and Divisional Forest Officer of Gorakhpur Forest Division for their active cooperation in the field work, and Dr. S. D. Pathak for their help in data collection. I am also grateful to Prof. R. P. Shukla for all round support and encouragement.

\section{References}

1. Barik, S.K., Tripathi, R.S., Pandey, H.N. and Rao, P.: Tree regeneration in a sub-tropical humid forest: Effect of cultural disturbance on seed production, dispersal and germination. Journal of Applied Ecology, 33, 1551-1560 (1996).

2. Callaghan, T.V.: Physiological and demographic implications of modular costruction in cold environment. Pp. 111-136. In D. Davy, M.J. Hutchings and A.R. Watkinson (eds.) Plant population ecology (1988).

3. Champion H.G. and Seth S.K.: A Revised Survey of the Forest Types of India. Government of India, New Delhi (1968).

4. Chapin, F.S., Reynolds, H. L., Antonio, D. C. and Eckhart, V.: Environmental responces of plants and ecosystems as predictors of the impact of global changes. Journal of Biosciences 18, 515-524 (1993).

5. Cook, R.E.: Clonal plant population. American Scientist 11, 244-253 (1983).

6. Daniels, R.J.R., Gadgil M. and Joshi N.V.: Impact of human extraction on tropical humid forests in the Western Ghats in Uttara Kannada, South India. Journal of Applied Ecology 32, 866-874, (1995).
7. Deka, J., Tripathi, O.P. and Khan. M.L.: High dominance of Shorea robusta Gaertn. in Alluvial Plain Kamrup Sal Forest of Assam, N. E. India. International Journal of Ecosystem 2, 67-73, (2012).

8. Gautam, M. K., Rajesh, K. M. and Tripathi, A. K.: Plant species diversity in unmanaged moist deciduous forest of Northern, India. Current Science, 25, 277-287, (2014).

9. Gentry, A.H.: Diversity and floristic composition of neotropical dry forests. In: Bullock S.H., Mooney H.A. and Medina E. (eds), Seasonally Dry Tropical Forests. Cambridge University Press, Cambridge, UK, pp. 146-194, (1995).

10. Halpern, C.B. and Spies, T.A.: Plant species diversity in natural and managed forests of the Pacific Northwest. Ecological Applications 5, 913934, (1995).

11. Hubbell, S. P. and Foster, R. B.: In Tropical Rain Forest; Ecology and Management (eds Whitmore, T. C. and Chadwic, A. C.), Blackwell Scientific Publication, Oxford, 25- 41 (1983).

12. Hubbell, S.P., Foster, R.B., O'Brien, S.T., Harms, K.E., Condit, R., Wechsler, B., Wright, S.J. and S. Loode Lao.: Light-gap disturbance, recruitment limitation, and tree diversity in a Neotropical forest. Science 283, 554-557 (1999).

13. Isley, D.: Leguminosae and Homo sapiens. Economic Botany 36, 289-315 (1982).

14. Khan, M.L., Rai, J.P.N. and Tripathi, R.S.: Population structure of some trees in disturbed and protected sub tropical forest or north- east India. Acta Ecologia, 8, 247-255, (1987).

15. Kimmins, J.P.: Forest ecology. Macmillan Publishing C., NY. (1987)

16. Knight, D.H.: A phytosociological analysis of species rich tropical forest on Barro Colorado Island, Panama. Ecological Monograph 45, 259-289, (1975).

17. Kushwaha, S.P.S. and Nandy, S.: Species diversity and community structure in sal (Shorea robusta) forests of two different rainfall regimes in West Bengal, India. Biodiversity and Conservation 21, 12151228, (2012).

18. Magurran, A.E.: Ecological Diversity and its Measurement. Princeton University Press, New Jersey, USA, (1988)

19. Majumdar, K., Shankar, U. and Dutta, B.K.: Tree species diversity and stand structure along major community types in lowland primary and secondary moist deciduous forests in Tripura, Northeast India. Journal of Forest Research 23, 553-568, (2012).

20. Mueller-Dombois, D. and Ellenberg, H.: Aims and Methods of Vegetation Ecology. John Wiley and Sons, Inc., New York, (1974). 
21. Murali, K.S., Shankar, U., Skankar, R.U., Ganeshaiah, K.N. and Bawa, K.S.: Extraction of non- timber forest products in the forests of Billigiri Rangan Hills, India. 2. Impact of NTFP extraction on regeneration, population structure and species composition. Economic Botany, 50, 252269 (1996).

22. Paine, R.: Food web complexity and species diversity. American Naturalist, 100 (1966).

23. Pandey, S.K. and Shukla, R.P.: Regeneration strategy and plant diversity status in degraded sal forests. Current Science 81, 95-102, (2001).

24. Pandey, S.K.: Population status and regeneration strategy of some perennial legumes in plantation forests of North-Eastern Uttar Pradesh, Ph.D. Thesis, DDU Gorakhpur University, Gorakhpur, India, (2000).

25. Sagar, R and Singh, J. S.: Structure, diversity, and regeneration of tropical dry deciduous forest of northern India. Biodiversity and Conservation, 14, 935959, (2005).

26. Shankar, U., Lama, S.D. and Bawa, K.S.: Ecosystem reconstruction through 'taungya' plantations following commercial logging of a dry, mixed deciduous forest in Darjeeling Himalaya. Forest Ecology and Management 102, 131-142, (1998).

27. Shankar, U.: A case of high tree diversity in sal (Shorea robusta)-dominated lowland forest of eastern
Himalaya: floristic composition, regeneration and conservation. Current Science 81, 776-786, (2001).

28. Silvertown, J.W.: Introduction to Plant Population. 2nd edn. ELBS/Longman, London, (1987)

29. Singh, J.S.: The biodiversity crisis: a multifaceted review. Current Science 82, 638-647 (2002).

30. Srivastava T.N.: Flora Gorakhpurensis. Today and Tomorrow's Printers and Publishers, New Delhi, India (1976).

31. Tripathi A. K. and UmaShankar: Patterns of species dominance, diversity and dispersion in 'Khasi hill sal' forest ecosystem in northeast India. Forest Ecosystem, 1-23 doi:10.1186/s40663-014 0023-2 (2014).

32. UNEP: India: State of the Environment. United Nations Environment Program. (2001)

33. Whittaker, R. H.: Communities and ecosystem. 2nd ed. Macmillan Publishing Co. Inc. New York (1975).

\section{Cite this article as:}

Sanjay Kumar Pandey. Species composition and diversity of legumes in sal plantations of northeastern Uttar Pradesh, India. Annals of Plant Sciences 6.9 (2017) pp. 1668-1675.

doi: http://dx.doi.org/10.21746/aps.2017.9.1

Source of support: Nil. 